\title{
Water hydrochemistry of Lake Boudaroua in the Moroccan Prerif west Mediterranean region
}

\author{
Hicham En-nkhili ${ }^{1, *}$, Issam Etebaai $^{2}$, Khadija El kharrim $^{1}$, and Driss Belghyti ${ }^{1}$ \\ ${ }^{1}$ Natural Resources and Sustainable Development, Department of Biology Ibn Tofail University, Faculty of Science Kenitra, Morocco \\ ${ }^{2}$ Laboratory of Research and Development in Engineering Sciences, Department of Earth and Environmental Sciences, Abdelmalek \\ Essaadi University, Faculty of Science and Technique, (Al Hoceima), Morocco
}

\begin{abstract}
In order to assess the quality of surface water of Boudaroua Lake, located in the Moroccan Prerif.The water quality parameters was used to evaluate the potential presence of toxicity of this ecosystem. To this end, samples and hydrochemical analyzes were carried out for five permanent stations around the Lake, during the study period (July 2019, October 2019, January 2020). The study was based on 11 parameters, namely, turbidity (TUR), dissolved oxygen (O2), total hardness (DT), calcium $\left(\mathrm{Ca}^{2+}\right)$, magnesium $\left(\mathrm{Mg}^{2+}\right)$, sodium $\left(\mathrm{Na}^{+}\right)$,potassium $\left(\mathrm{K}^{+}\right)$, ammonium $\left(\mathrm{NH}_{4}^{+}\right)$, chloride $\left(\mathrm{Cl}^{-}\right)$, sulfate $\left(\mathrm{SO}_{4}^{2-}\right)$, nitrate $\left(\mathrm{NO}_{3}^{-}\right)$were considered. The results obtained of these physicochemical parameters have been compared with the Moroccan standard (MS) for surface water and with the World Health Organization (WHO). The results indicated that the values of the physicochemical parameters varies significantly seasonally due to precipitation rate variation. In addition the impact of Agricultural pollution resulting from the excessive use of fertilizers that enter the lake through waterways, such as ammonium $\mathrm{NH}_{4}^{+}$, and dissolved oxygen $(\mathrm{O} 2)$ its value reaching respectively $1.09 \mathrm{mg} / \mathrm{L}, 12 \mathrm{mg} / \mathrm{L}$ remains above standards (MS) and (WHO) which could harm the ecosystem of the lake.
\end{abstract}

\section{Introduction}

Water plays a very important role for all living beings. However, the rapid evolution in different sectors including agriculture, industry and urban activities, especially around lakes, has caused significant changes in the quality and quantity of these water resources [1]. Eutrophication caused by nutrient enrichment of lakes is considered one of the major environmental problems in the world[2].Water quality analysis can be useful to prevent pollution of lakes and cede correct information to the decision maker for the management of the aquatic environment[3]. Morocco, where the climate is semi-arid like most of the Mediterranean countries, is also affected by climate change appearing by the irregular precipitation and longer dry seasons[4], which cause the difficulty of renewing water resources. There is a need to properly assess the spatial and temporal pattern of water quality in lake systems, which is influenced by various factors [5]. However, the waters of these systems influencing different pollution problems especially small lakes such as, Boudaroua lake, which is considered the only natural park in Ouazzane city, where it is easy to access by tourists to practice their anthropic activities which harms the quality of water.

The objective of this work is to determine the quality of surface water in this Lake by comparing the results of Moroccan standards for surface water (MS) [6] and those of the World Health Organization (WHO) [7]. In addition, study the level of eutrophication of Boudaroua Lake.

\section{Study methodology}

\subsection{Study area}

The boudaroua lake $\left(34^{\circ} \mathrm{N} 47^{\prime}\right.$ and $\left.05^{\circ} \mathrm{W} 27^{\prime}\right)$ is located approximately $3 \mathrm{~km}$ from Ouazzane city (Figure 1). The first role of the construction this lake, during the protectorate around 1936 is it to supply the town of the city with drinking water. Currently, it has become a natural park for fishing.

The body of water is located at an altitude of $210 \mathrm{~m}$ and reaches an area of 13 ha at its maximum extension. The perimeter of the water body is $2 \mathrm{~km}$, the water depth is variable and it can reach up to $8 \mathrm{~m} \mathrm{[8]}$.

Lake water comes mainly from springs and rainfalls in addition to waterways. The loss of water is ensured by evaporation during dry seasons and also by downstream weir allowing the evacuation of excess water during floods.

On the geological side, the Ouazzane region is connected by the Mediterranean Alpine system, resulting in the three series of tectonic movements, the first causing the formation of numerous Jurassic scales, covered by marls [9].

\footnotetext{
Corresponding author: hicham.cpr@gamil.com
} 
During hot periods, temperatures vary between $19^{\circ} \mathrm{C}$ and $32^{\circ} \mathrm{C}$ and in cold periods, they vary between $6{ }^{\circ} \mathrm{C}$ and $14{ }^{\circ} \mathrm{C}$. The average annual precipitation is $800 \mathrm{~mm}$ with an irregular distribution.

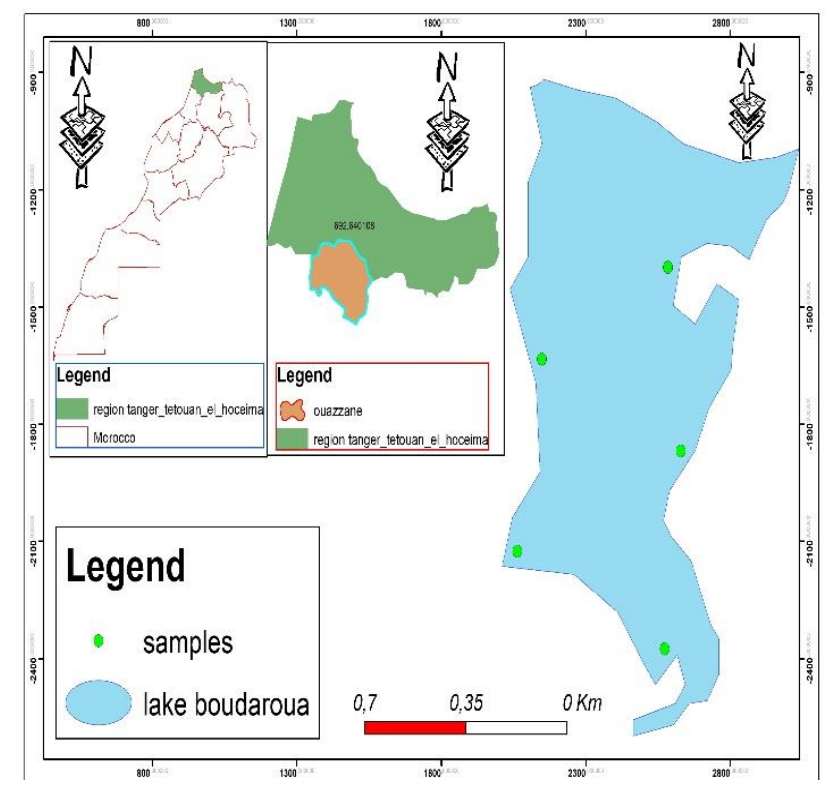

Figure .1. Geographic location of Boudaroua Lake.

\subsection{Material and methods}

In order to evaluate the water quality of the lake, five sites monthly sampling were used. The samples were collected in $2 \mathrm{~L}$ pre-cleaned polyethylene bottles for June 2019, October 2019, and January 2020. Before sampling, the entire sample container was washed and rinsed thoroughly with lake water.

The physical parameters of the waters such as temperature, dissolved oxygen (DO), were measured in situ. On the other hand, samples of the water were transported in a cooler at $4{ }^{\circ} \mathrm{C}$ to the laboratory (Agrilabs) based in Larache to analyze them within an hour following the sampling according to the techniques described by Rodier[10].

The physico-chemical parameters measured in the laboratory are total hardness (TH), turbidity (TUR), chloride $\left(\mathrm{Cl}^{-}\right), \quad$ Nitrate $\left(\mathrm{NO}_{3}^{-}\right), \quad$ sulfates $\left(\mathrm{SO}_{4}^{2-}\right)$, sodium $\left(\mathrm{Na}^{+}\right)$, potassium $\left(\mathrm{K}^{+}\right)$, Magnesium $\left(\mathrm{Mg}^{2+}\right)$, calcium $\left(\mathrm{Ca}^{2+}\right)$ and Ammonium $\left(\mathrm{NH}_{4}^{+}\right)$. Statistical analysis of collected data was done by Excel 2013 software.

\section{Result and discussion}

\subsection{Dissolved oxygen}

The dissolved oxygen content measures the concentration of dissolved oxygen in the water. Oxygen is the most important gas for all living things, especially aquatic organisms (respiration and Photosynthesis) and in addition to the mineralization of biomass (Figure 2). The measurements carried out show that the oxygenation rate is higher in all the stations $(>7 \mathrm{mg} / \mathrm{L})$ with a significant flow in the winter month and this increase is due to the decrease in the water temperature and the greater mixing of the waters by the wind. The variation of dissolved oxygen in the water sample taken was 5.8 to $10 \mathrm{mg} / \mathrm{L}$ (June 2019, summer); 6.6 to $9 \mathrm{mg} / \mathrm{L}$ (October 2019, autonomous); 9.5 to $12 \mathrm{mg} / \mathrm{L}$ (January 2019, winter) respectively.

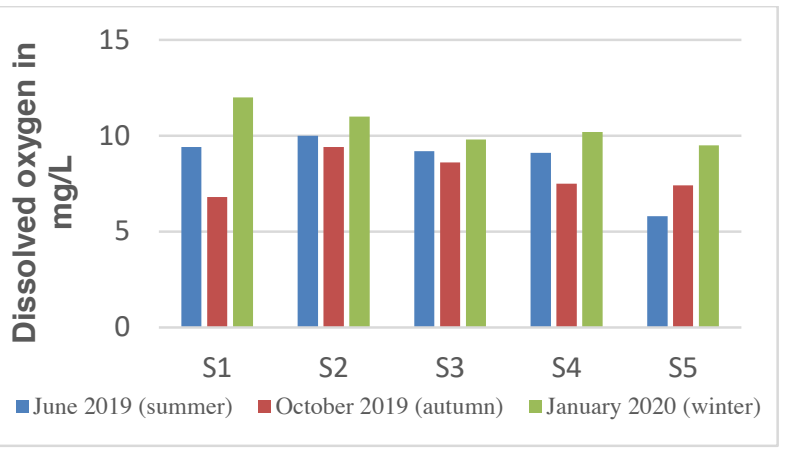

Figure. 2. Spatio-temporal evolution of the dissolved oxygen of Boudaroua.Lake

\subsection{Turbidity}

Turbidity reflects, on the one hand, the presence in water of particles in mineral or organic, living or detrital and on the other hand the capacity to diffuse or absorb the incident light from the atmosphere (Figure 3). The measurements carried out show that the turbidity of the body of aquatic water varies very little in the space of order 0.54 , on the other hand, the seasonal variation is very important of order 3.22 , this variation is explained on the one hand by the precipitation and runoff which suspends interface sediments by homogenization of the body of water during January and on the other hand to the mineralization of organic matter after the death of aquatic vegetation [11].

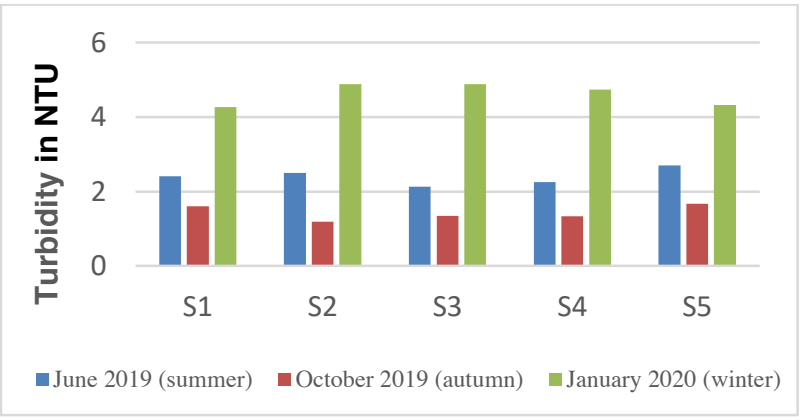

Figure. 3. Spatio-temporal evolution of turbidity of Boudaroua Lake.

\subsection{Total hardness}

Total hardness expresses the quantities of cations dissolved in water, in particular calcium and magnesium. Total hardness measurements for the entire water sample are much lower. Generally, the water of Boudaroua Lake is very soft according to standards proposed by Manivasakam [12] (Table 1) (Figure 4). 
Table .1. Water quality vs hardness

\begin{tabular}{|c|c|}
\hline Types of water & $\begin{array}{c}\text { Hardness in } \mathrm{mg} / \mathrm{L} \text { of } \\
\mathrm{CaCO}_{3}\end{array}$ \\
\hline Soft water & $0-50$ \\
\hline Moderately Soft & $50-100$ \\
\hline Neither hard nor soft & $100-150$ \\
\hline Moderately hard & $150-200$ \\
\hline Hard water & $200-300$ \\
\hline Very hard & $>300$ \\
\hline
\end{tabular}

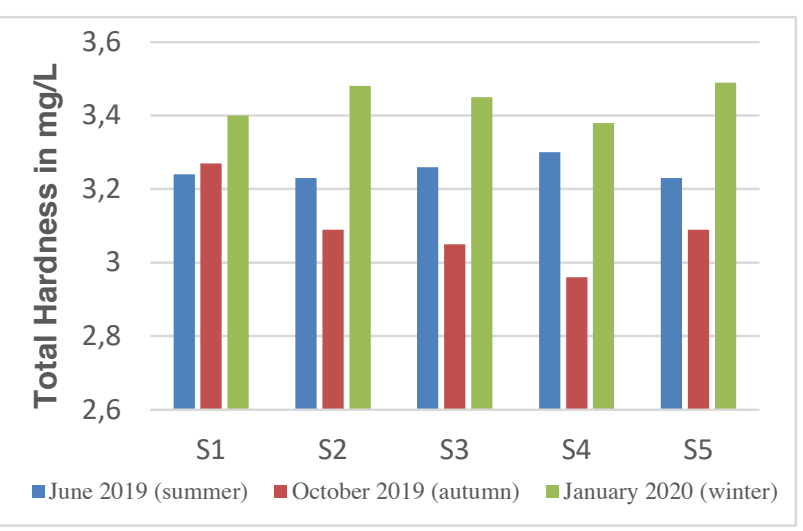

Figure .4. Spatio-temporal evolution of total hardness of Boudaroua Lake.

\subsection{Ammonium}

The variation of ammonium in the water sample taken was from 1.04 to $2.14 \mathrm{mg} / \mathrm{L}$ (October 2019, autonomous); from 0.32 to $1.14 \mathrm{mg} / \mathrm{l}$ (January 2019, winter) respectively (Figure 5). These very important contents (higher than the Moroccan standards $0.5 \mathrm{mg} / \mathrm{L}$ ) let predict that this element constitutes a risk of pollution for the surface waters of Boudaroua Lake.

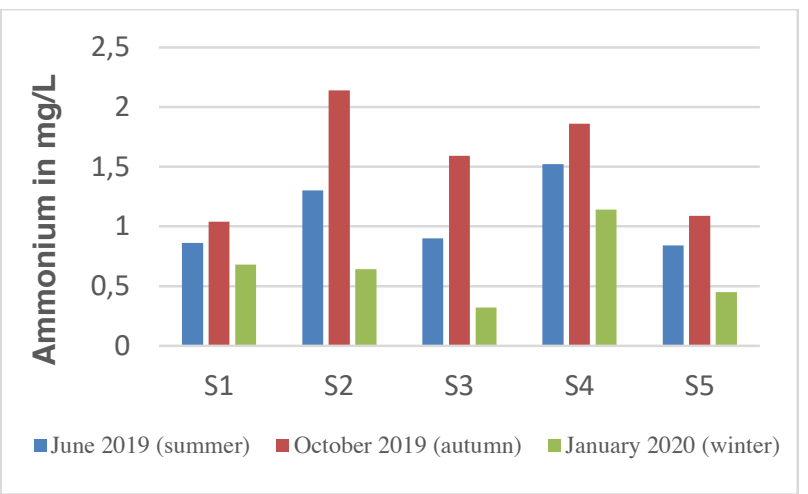

Figure .5. Spatio-temporal evolution of ammonium of Boudaroua Lake.

\subsection{Nitrate}

The variation of nitrate in the water sample taken was from 0.46 to $1.17 \mathrm{mg} / \mathrm{L}$ (June 2019, summer); 7.79 to $10.65 \mathrm{mg} / \mathrm{L}$ (October 2019, autumn); 1.9 to $2.6 \mathrm{mg} / \mathrm{L}$ (January 2019, winter) respectively (Figure 6).

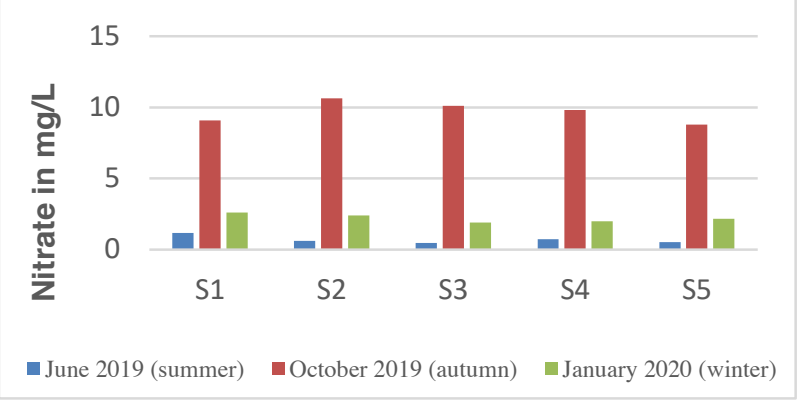

Figure .6. Spatio-temporal evolution of nitrate of the water of Boudaroua Lake.

\subsection{The major cations}

In the water of lake Boudaroua, the tendency of the predominant cations was of the order of $\mathrm{Na}^{+}>\mathrm{Ca}^{2+}>\mathrm{Mg}^{2+}>$ $\mathrm{K}^{+}$with Sodium being a dominant cation.

The distributions of cations concentrations in the water of Boudaroua Lake were not significant fluctuations during different periods except sodium, this variation reflects the climatic influence by dilution of water during the winter season. The variation of sodium in the water sample taken was 270.6 to $290.65 \mathrm{mg} / \mathrm{L}$ (June 2019, summer); from 211.97 to $227.72 \mathrm{mg} / \mathrm{L}$ (October 2019, autumn); from 227.35 to $231.45 \mathrm{mg} / \mathrm{L}$ ) respectively (Figure 7).

These values remain above the limit value of (WHO). The variation of potassium in the water sample taken was 2.82 to $6.85 \mathrm{mg} / \mathrm{l}$ (June 2019, summer); 3.41 to $4.54 \mathrm{mg} / \mathrm{L}$ (October 2019, autumn); 4.09 to $4.59 \mathrm{mg} / \mathrm{L}$ (January 2020, winter) respectively. Potassium is less than sodium due to its greater resistance to weathering and the formation of clay minerals (Figure 10).

Calcium is essential from rock, limestone, and industrial waste. The main source of magnesium is an influx of wastewater and minerals are generated by soil erosion [13].

The variation of magnesium in the water sample taken was from 13.12 to $14.12 \mathrm{mg} / \mathrm{L}$ (June 2019, summer); 15.06 to 15.94 (October 2019, autonomous); 14.58 to $15.32 \mathrm{mg} / 1$ (January 2020, winter) respectively (Figure 9).

The variation of calcium in the water sample taken was from 71.95 to $82.84 \mathrm{mg} / \mathrm{L}$ ((June 2019, summer); 65.08 to $71.81 \mathrm{mg} / \mathrm{L}$ (October 2019, autumn); 75.22 to $77.81 \mathrm{mg} / \mathrm{L}$ (January 2020, winter) respectively (Figure 8).

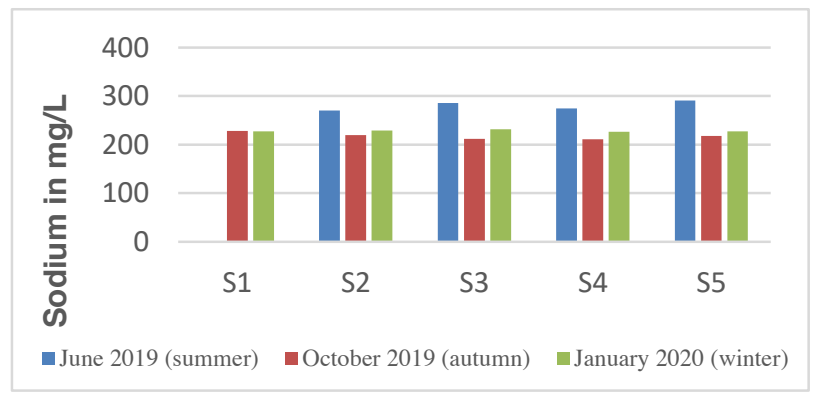

Figure. 7. Spatio-temporal evolution of sodium of Boudaroua Lake. 


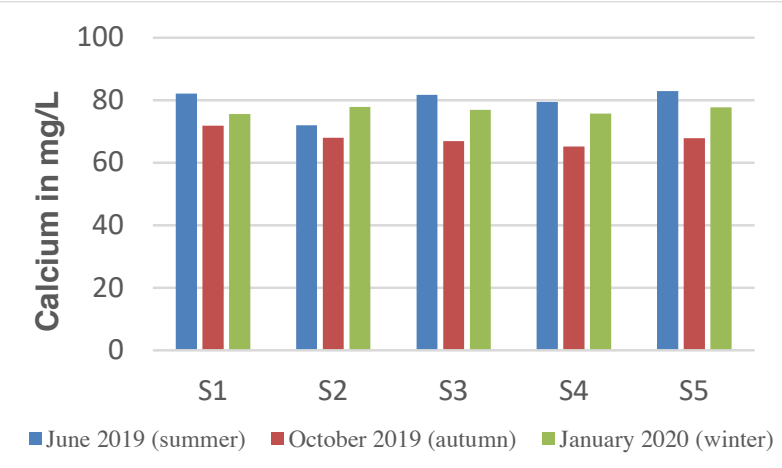

Figure .8. Spatio-temporal evolution of calcium of Boudaroua Lake.

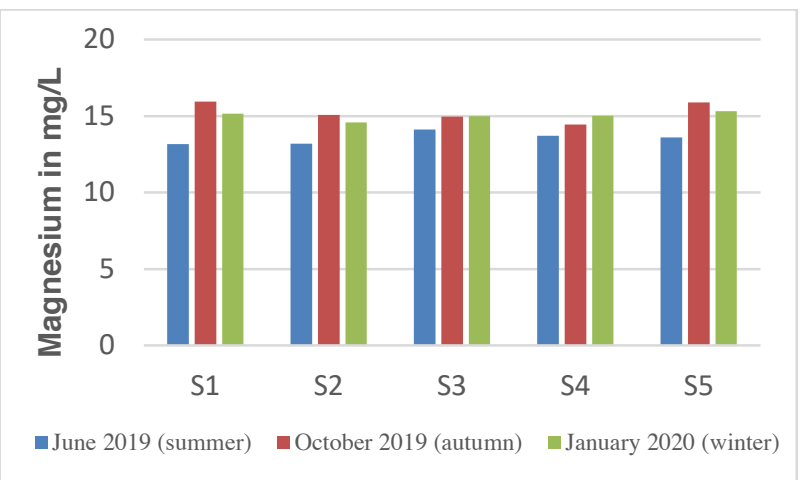

Figure .9. Spatio-temporal evolution of magnesium of Boudaroua Lake.

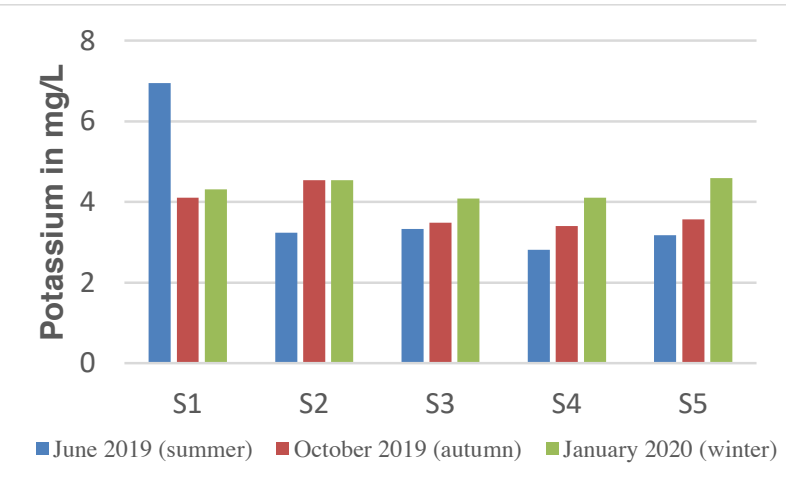

Figure .10. Spatio-temporal evolution of potassium of Boudaroua Lake.

\subsection{Major anions}

The predominant anionic tendency was of the order of $\mathrm{Cl}^{-}>\mathrm{HCO}_{3}^{-}>\mathrm{SO}_{4}^{2-}$, chloride being the dominant anion. Generally associated with sodium ion, its sample content is between 218.4 to $240 \mathrm{mg} / \mathrm{L}$ (June 2019, summer); 297.06 to $320.92 \mathrm{mg} / \mathrm{l}$ (October 2019, autonomous); 420 .84 to $423.86 \mathrm{mg} / \mathrm{L}$ (January 2019, winter) respectively (Figure 11). The values remain higher than the limit value considered $(250 \mathrm{mg} / \mathrm{L}, \mathrm{WHO})$. This increase can explain, on the one hand, a strong dilution of water and on the other by the contamination resulting from leaching of agricultural land around the lake with the first precipitation in autumn.

Bicarbonates result from the physicochemical balance between rock, water, and carbon dioxide according to the following general equation [14] (Figure 12).

$$
\mathrm{XCO}_{3}+\mathrm{CO}_{2}+\mathrm{H}_{2} \mathrm{O} \leftrightarrow \mathrm{X}^{2+}+2 \mathrm{HCO}_{3}^{-}
$$

Where $(\mathrm{X})$ can be $\left(\mathrm{Ca}^{2+}\right)$ or $\left(\mathrm{Mg}^{2+}\right)$. It varies between 144.88 to $167.75 \mathrm{mg} / \mathrm{L}$ (June 2019, summer); from 228.75 to $277.5 \mathrm{mg} / \mathrm{L}$ (October 2019, autumn); from 167.75 to $190.63 \mathrm{mg} / \mathrm{L}$ (January 2020, winter).

The sulfates in the lake water come mainly from rainwater and evaporitic sedimentary rocks, notably gypsum $\left(\mathrm{CaSO}_{4}\right)$, pyrite $(\mathrm{FeS})$ according to the following equation [15] (Figure 13).

$$
4 \mathrm{FeS}_{2}+15 \mathrm{O}_{2}+14 \mathrm{H}_{2} \mathrm{O} \rightarrow 4 \mathrm{Fe}(\mathrm{OH})_{3}+16 \mathrm{H}^{+}+8 \mathrm{SO}_{4}^{2-}
$$

And do not forget the influence the use of chemical fertilizers. It varies for the water sample taken from 53.53 to $54.89 \mathrm{mg} / \mathrm{L}$ (June 2019, summer); 40.01 to $44.74 \mathrm{mg} / \mathrm{L}$ (October 2019, autonomous); 42.21 to $44.36 \mathrm{mg} / \mathrm{L}$ (January 2019, winter) respectively. These values remain below the Moroccan standard $(<250 \mathrm{mg} / \mathrm{L})$.

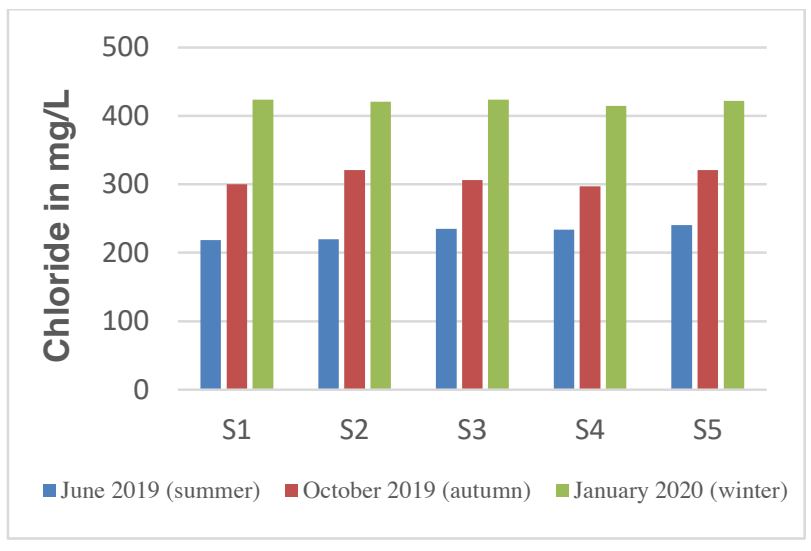

Figure .11. Spatio-temporal evolution of chloride of Boudaroua Lake.

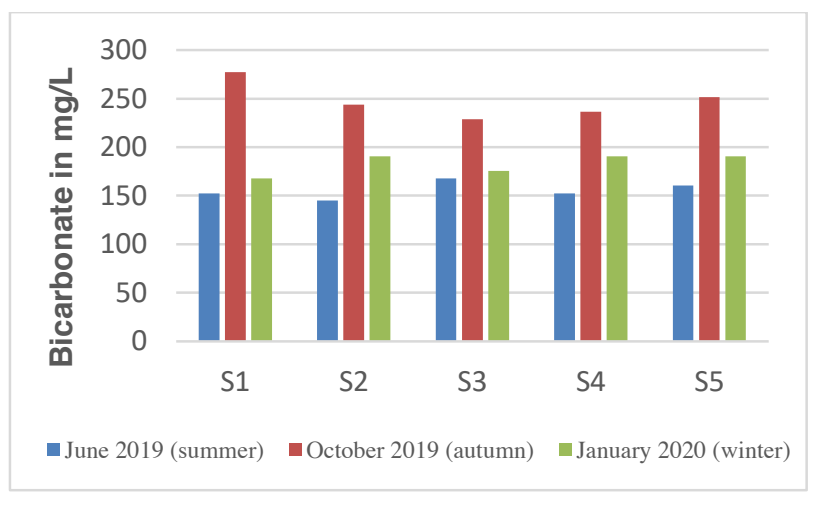

Figure .12. Spatio-temporal evolution of bicarbonate of Boudaroua Lake. 


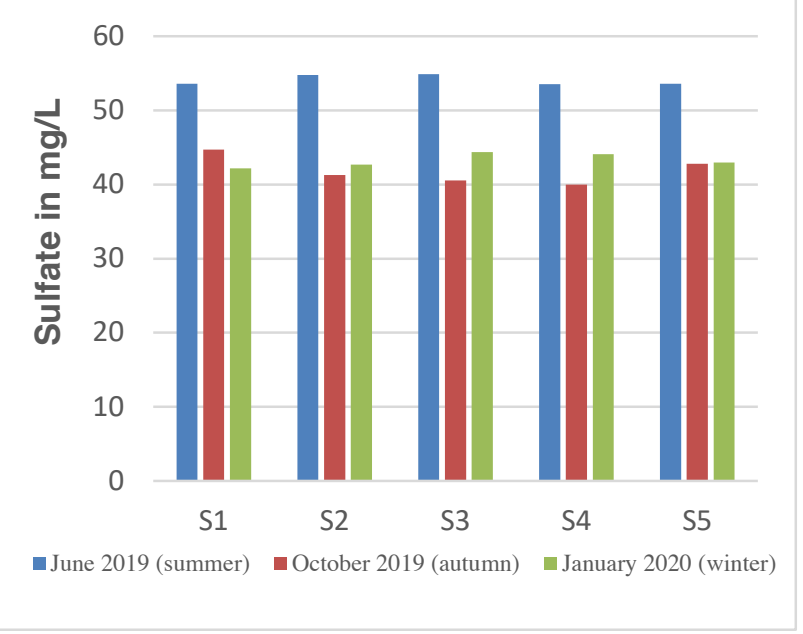

Figure .13. Spatio-temporal evolution of sulfate of Boudaroua Lake.

\subsection{Chemical facies}

The use of the diagram of piper and Schoeller Berkaloff makes it possible to determine the chemical facies in order to obtain the type of surface water by the representation of the results of chemical analyzes on Diagram software. For the case of Lake Boudaroua, the pace general diagram of piper and Schoeller Berkaloff shows that the dominant chemical facies is potassium-chlorosodium (Figures 14 \& $15)$.

\section{Conclusion}

This work was carried out to determine the health status of Lake Boudaroua., based on the results of physicochemical analyzes, which were carried out for five permanents sites during a study period spanning three months (summer 2019, October 2019, January 2020) and then the water quality index calculation.

Physicochemical analyzes show that these waters are of potassium-chlorosodium type with a high dilution due to climatic variations from one season to another. Also, biodegradable and non-biodegradable substances can be brought by agricultural and anthropogenic activities favor which promotes the eutrophication of this body of water and consequently the deterioration of their quality. The results also showed that most parameters do not exceed the maximum values specified by Moroccan standards (MS) and world health organization (WHO) except for ammonium $\left(\mathrm{NH}_{4}^{+}\right)$and dissolved oxygen (DO). Sensitizing the population and the companies producing the waste contributes to the conservation of aquatic plans.

For a better understanding of the hydrogeochemical functioning of Lake Boudaroua vis-a-vis the climatic and anthropic impact, the study must be completed by a seasonal monitoring of the physico-chemistry of the water at the level of the water column up to at the watersediment interface.

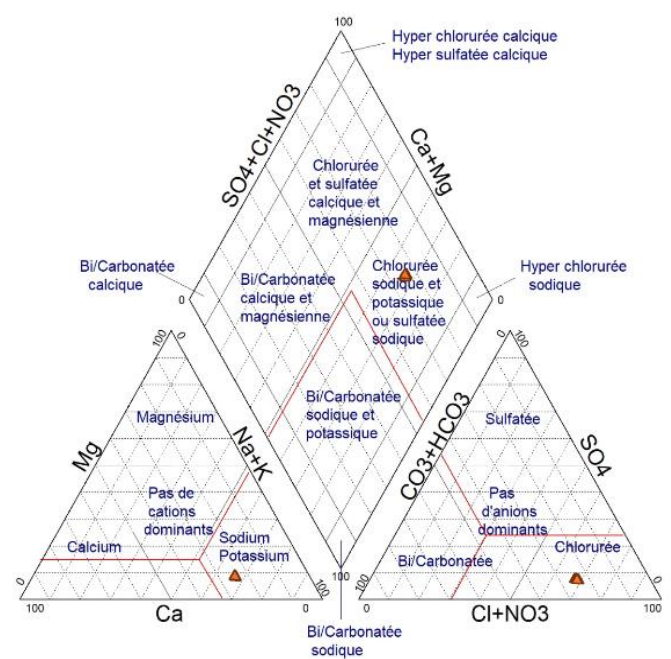

Figure .14. Graphical representation of the water chemical composition of Lake Boudaroua according to Piper diagram.

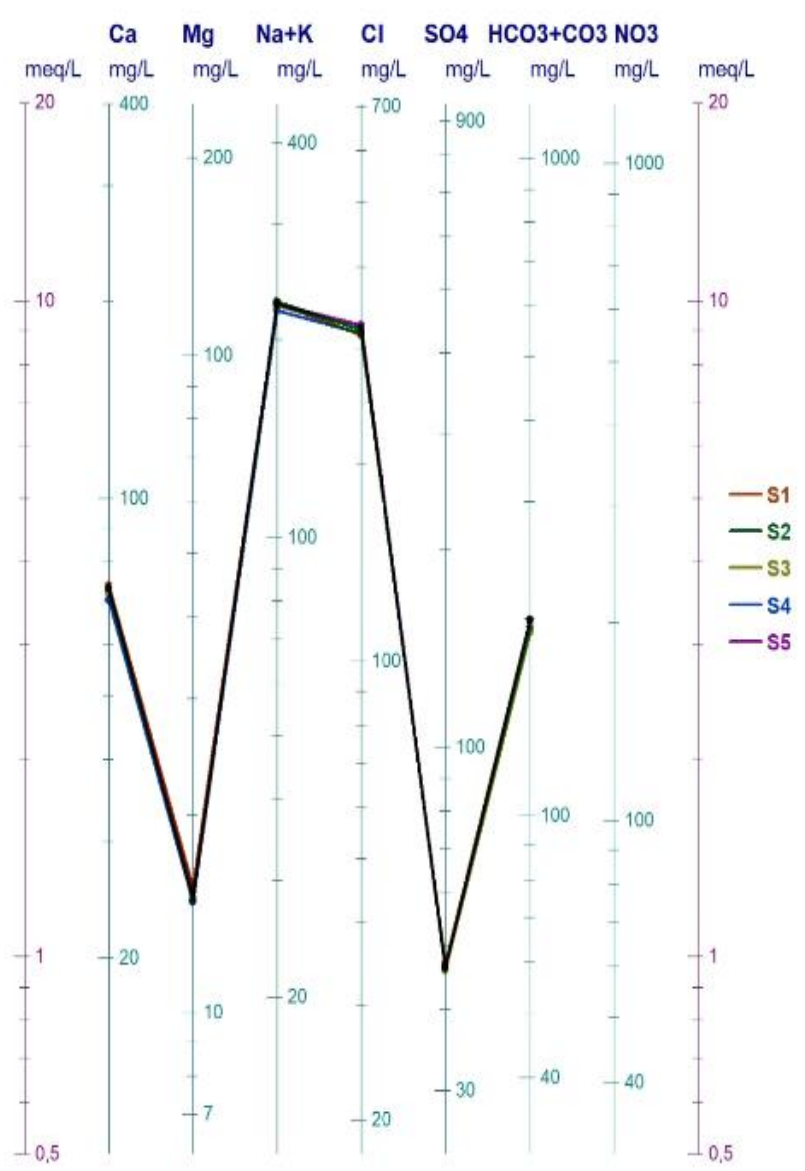

Figure .15. Graphical representation of the water chemical composition of lake Boudaroua according to Schoeller Berkaloff diagramm.

Acknowledgments. Our thanks go to the members of the food and environment laboratory (AGILABS)-Larache for their help in the physicochemical analyses. 


\section{References}

1. K. Zeinalzadeh and E. Rezaei, Journal of Hydrology: Regional Studies 13, 1 (2017).

2. A. Oczkowski and S. Nixon, Estuarine, Coastal and Shelf Science 77, 309 (2008).

3. S. Yao, B. Xue, and D. Kong, Chin. Geogr. Sci. 20, 202 (2010).

4. H. En-nkhili, M. Najy, I. Etebaai, F. Z. Talbi, K. El Kharrim, and D. Belghyti, in Proceedings of the 4th Edition of International Conference on Geo-IT and Water Resources 2020, Geo-IT and Water Resources 2020 (ACM, Al-Hoceima Morocco, 2020), pp. 1-5.

5. H. S. Xu, Z.X. Xu, W. Wu, and F. F. Tang, Procedia Environmental Sciences 13, 1641 (2012).

6. Mcatee, “Arrêté conjoint du Ministre chargé l'Aménagement du Territoire, de l'Eau et de l'Environnement n²028-03 du 10 Ramadan 1424 (5 Novembre 2003) fixant les normes de qualité des eaux piscicoles," Bull. Off. n 5196 du 18/03/2004, 5196, pp. 5-7, 2003

7. W. H. Organization, WHO Guidelines for DrinkingWater: Quality Policies and Procedures Used in Updating the WHO Guidelines for Drinking-Water Quality (World Health Organization, 2009).

8. I. Etebaai, B. Damnati, and M. Taieb, 10 (2010).

9. G. Suter, Notes et Mémoires Du Service Géologique Du Maroc 24, 7 (1965).

10. J. Rodier, B. Legube, and N. Merlet, Entièrement Mise à Jour, Dunod, Paris (2009).

11. I. Etebaai, B. Damnati, H. Benhardouze, O. Benhardouze, H. Reddad, M. Maâtouk, and M. Taieb, African Geosciences Review 15, 303 (2008).

12. R. Udhayakumar, P. Manivannan, K. Raghu, and S. Vaideki, Ecotoxicology and Environmental Safety 134, 474 (2016).

13. K. Ramesh and K. Seetha, International Journal of Research in Chemistry and Environment (IJRCE) 3, 36 (2013).

14. F. J. Millero, J. M. Santana-Casiano, and M. González-Dávila, J Solution Chem 39, 543 (2010).

15. D. K. Nordstrom, D. W. Blowes, and C. J. Ptacek, Applied Geochemistry 57, 3 (2015). 